Historia Slavorum Occidentis

2017, $\mathrm{nr} 4$ (15)

ISSN 2084-1213

DOI: $10.15804 /$ hso 170403

\author{
Piotr Prokopiuk (Lublin)
}

\title{
Stosunki Gruzji z Europą Zachodnią i państwem polsko-litewskim w latach 1453-1783
}

Słowa kluczowe: Gruzja, papiestwo, Rzeczpospolita, Turcja, dyplomacja

Keywords: Georgia, Papacy, Republic of Poland, Turkey, diplomacy

\begin{abstract}
The article presents the history of contacts between Georgia and Western Europe as well as Georgia and the Polish-Lithuanian Commonwealth between the mid-15 ${ }^{\text {th }}$ and the end of the $18^{\text {th }}$ centuries. In the article, the role of the Georgian diplomatic missions is emphasized in the process of forging anti-Osman coalitions.
\end{abstract}

Upadek Konstantynopola pod naporem sunnickich Turków osmańskich uczynił Gruzję jednym z kluczowych celów ekspansji sułtanatu ${ }^{1}$. Na domiar złego zakaukaska monarchia Bagratydów, ulegająca postępującej fragmentacji feudalnej na wzajemnie zwalczające się królestwa i księstwa, z początkiem XVI w. zyskała kolejnego śmiertelnego wroga - szyicką Persję Safawidów². Chrześcijańska wysepka

1 Operacje militarne rozpoczęto już w 1454 r. splądrowaniem księstw Abchazji, następnie Samcche-Saatabago i Gurii. Turcja dążyła do uczynienia wód Morza Czarnego akwenem osmańskim, a podbój ziem gruzińskich pozwalał przejąć kontrolę nad genueńskimi i weneckimi szlakami handlowymi, przebiegającymi ze Wschodu poprzez newralgiczny region Zakaukazia ku Europie Zachodniej oraz Polsce i Moskwie, a co równie istotne uzyskać strategiczną przewagę geopolityczną w przyszłej rywalizacji z Persją. Zob. Z. Tsurtsumia, Abkhazia in Russian-Ottoman relations (From the second half of the XV c. to the first quarter of the XXc.), Tbilisi 2009.

2 Szach Ismail I (1501-1524) prawdopodobnie już w pierwszych latach swoich rządów podpo- 
na muzułmańskim morzu zmuszona była pospiesznie rozpocząć poszukiwania sojuszników w wierze. Położenie najbliższych, pozbawionych niezależnego organizmu państwowego Ormian i tracących ostatnie bastiony bizantyjskiej cywilizacji Greków, przeprowadzenie skutecznych ruchów dyplomatycznych czyniło wówczas przedsięwzięciem jeszcze trudniejszym.

Wydźwięk tragedii konstantynopolitańskiej z dnia 29 V 1453 r. $^{3}$ jednak znacznie przyspieszył proces jednoczenia sił europejskich. Inicjatywę zawiązania koalicji antyosmańskiej podjęło papiestwo, kierując tym samym (jednocześnie z permanentnym postulatem unifikacji wschodnich struktur kościelnych pod katolicką kuratelą) pomocną dłoń do dyplomacji gruzińskiej. Ówczesny papież Kalikst III realizację karkołomnego zadania na wschodniej flance wroga powierzył (na mocy postanowień bulli z dnia 15 V 1455 r.) ${ }^{4}$ nuncjuszowi na Kaukaz Ludovicowi Bolonii (Ludovico de Bologna) $)^{5}$, który po misji w Etiopii zawitał do Gruzji w 1456 r. Dyplomata pesymistycznie raportował kurii rzymskiej o stanie królestwa oraz lokalnego Kościoła, iż: „...(Gruzini) są skłóceni z wielką wzajemną nienawiścią i prowadzą wojnę (między sobą)" ${ }^{6}$. W między czasie nowy papież Pius II, podobnie jak jego poprzednik, marząc o wyzwoleniu świata od zagrożenia tureckiego, z dniem 26 IX 1459 r. na kongresie władców chrześcijańskich w Mantui zaapelował o zorganizowanie nowej wyprawy krzyżowej ${ }^{7}$. Wkrótce swój akces do tworzącej się z wielkim trudem koalicji antytureckiej potwierdzili władcy gruzińscy: król Jerzy (Giorgi) VIII i atabeg ${ }^{8}$

rządkował sobie państewka wschodniogruzińskie. Zob. M. Brosset, Histoire de la Georgie, vol. 2, Sankt-Petersburg 1849/57, s. 446; D. Rayfield, Edge of Empires: A History of Georgia, London 2012, s. 164.

3 The Fall of the Byzantine Empire: A Chronicle by George Sphrantzes 1401-1477; thum. M. Philippides, Amherst 1980, s. 70.

4 Kalikst III utrzymał bullę (z dnia 30 IX 1455 r.) wydaną przez swojego poprzednika, Mikołaja V, która to nawoływała do podjęcia zbrojnej wyprawy przeciwko sultanowi, Mehmedowi II. Papież wyznaczył dodatkowo dzień wymarszu armii „wszystkich chrześcijańskich książąt i narodów" przeciw muzulmanom na 1 III 1456 r.; K.M. Setton, The Papacy and the Levant (1204-1571): The fifteenth century, Vol 2, Filadelfia 1978, s. 165.

5 Bullarium Franciscanum, T. 3 (1949), s. 205.

6 M. Tamaraszwili, Istoria katolikobisa kartwelta szoris, Tbilisi 1902, s. 56-64.

7 Zob. M. Angold, The Fall of Constantinople to the Ottomans: Context and Consequences, Harlow 2012.

8 Tytuł „atabeg” (gruz.: sonsßşo - atabagi) był jednym z najważniejszych nieformalnych urzędów w monarchii gruzińskiej, ustanowionym przez królową Tamarę I Wielką w $1212 \mathrm{r}$. W 1334 r. tytuł ten stał się dziedzicznym w możnowładczej rodzinie Dżakeli (gruz.: 叉ð১yjmo - Jakeli), książąt rządzących prowincją Samcche-Dżawachetią (Meschetią); A. Mikaberidze, His- 
Kwarkwaradze II Dżakeli ( Jakeli). Atabeg Samcche-Saatabago buńczucznie zapewnił swych potencjalnych sojuszników listownie, iż uczynił „pokój z wszystkimi sąsiadami”, postanowił „użyć wszystkie swoich sił i środków przeciwko Turkom” oraz obiecał w imieniu swoim, jak i kartlijskego partnera „wypędzić wrogów i pozostać (panem) Anatolii w ciągu jednego lata"'. Sojusz uzupełnili: cesarz trapezuncki Dawid II Wielki Komnen, gruzińscy książęta z rodu Dadiani i Gurieli oraz turkmeński władca Uzun Hasan (Hassan). W nieoficjalnych planach pojawiła się nawet osoba cesarza Etiopii Konstantyna I (Zara Yaqob) ${ }^{10}$. Listy za sprawą Ludovica Bolonii i uformowanej przez niego delegacji kaukaskiej w 1460 r., w skład której wchodzili Gruzini: biskup Nikoloz z Tbilisi i Kasadan (Kusudan) Kwarczichan z Megrelii ${ }^{11}$, drogą wodną poprzez Morze Czarne i Dunaj trafily do najważniejszych przywódców zachodnioeuropejskich: cesarza Fryderyka III Habsburga, weneckiego doży Pasquala Malipiero, florenckiego rodu Medyceuszy, papieża Piusa II, mediolańskiego księcia Franciszka I Sforzy, burgundzkiego księcia Filipa Dobrego, ostatecznie stając się w maju 1461 r. punktem rozważań na dworze francuskim Ludwika XI Walezjusza $^{12}$. Pozbawione politycznego realizmu deklaracje Kwarkwaradzego II oraz „egzotyczność” sojuszników zakaukaskich nie wpłynęły na polityczną konsolidację obozu europejskiego ku entuzjastycznemu podjęciu szeroko zakrojonych przygotowań do krucjaty. Pozyskano jedynie niewielkie lądowe posiłki burgundzkie i węgierskie oraz flotę wenecką, a także ochotników polskich, którzy to w zapale do walki z niewiernymi „dnia trzeciego miesiąca kwietnia (1464 r.), zmówiwszy się z sobą, (...) rzucili się na (krakowskich) Żydów i ich domostwa, powyłamywali mieszkania i synagogi i wszystkie majątki żydowskie rozerwali”'13. Fantasmagoryjny projekt kru-

torical Dictionary of Georgia, 2015, s. 123; C. Toumanoff, Studies in Christian Caucasian history, 1963, s. 438.

9 Cyt. za: D. Rayfield, Edge of Empires, s. 157-158.

10 W koalicji (określanej, jako „Wschodnia Liga”) mogli znajdować się władcy nie wymienieni w opisywanej korespondencji: rządzący Abchazją Rabia oraz Ismail Bej, władca Synopy i Ibrahim II Karamanid, emir Kamaranu. F. Babinger, Mehmed the Conqueror and His Time, Princeton 1992, s. 187.

11 Pio II, I Commentarii, L. V, 11, Mediolan 2004, s. 899.

12 Szerzej o działalności dyplomatycznej nuncjusza traktuje: A. Bryer, Ludovico Da Bologna and the Georgian and Anatolian Embassy of 1460-1461, Bedi Kartlisa. Revue de Kartvelologie, XIX-XX (1965), s. 178-198. Zob. G. Paiczadze, The anti-Turkish coalition of European countries and Georgia in the 1460, Tbilisi 1984, s. 88-105.

13 J. Długosz, Roczniki czyli kroniki sławnego Królestwa Polskiego, księgi IX-XII (wybór), s. 61, [PDF]. 
cjaty, oparty na nieskoordynowanych i zdemoralizowanych wojskach europejskich oraz na przeszacowanych siłach osaczonego Trapezuntu (30 tys.), rozbitej Gruzji (70 tys.) i zniewolonej Armenii (20 tys. $)^{14}$, dziwić nie mógł jedynie samego inicjatora krucjaty, papieża Piusa II, który zamierzał „wyjść osobiście na tę wyprawę”, a także listownie nakłonić sultana Mehmeda II Zdobywcę do wyrzeczenia się islamu na rzecz wiary chrystusowej ${ }^{15}$.

Fiasko inicjatywy papieskiej nie odwiodło skłóconych ze sobą przedstawicieli dynastii Bagratydów od podjęcia kolejnych wysiłków dyplomatycznych, skierowanych ku państwom europejskim. Upadek ostatniego bastionu bizantyjskiego, Cesarstwa Trapezunckiego, 15 VIII $1461 \mathrm{r} .{ }^{16}$ wpłynął już oficjalnie na poszerzenie grona adresatów gruzińskich próśb pomocy o państwa rządzone przez Jagiellonów - najpotężniejszą dynastię środkowo-wschodniej Europy, która dążyła do utrzymania swojej strefy wpływów nad coraz bardziej osmańskim Morzem Czarnym. Wysiłkiem niestrudzonego Ludovica Bolonii, krzewiącego ideę krucjaty tym razem na dworze polskim, doszło do pierwszych rozmów polsko-gruzińskich w $1471 \mathrm{r}$. Wysłannicy Kazimierza IV Jagiellończyka spotkali się w senacie Republiki Weneckiej z ambasadorami kartlijskiego króla Konstantego II oraz węgierskiego króla Macieja Korwina (Hunyadi Mátyás). Prawdopodobnie dzięki determinacji władcy Ak Kojunlu ${ }^{17}$, Uzun Hasana, doszło do finalizacji tajnych układów antytureckich z władcą polsko-litewskim ${ }^{18}$. Rok później do egzotycznej koalicji za namową weneckiego ambasadora Caterina Zeno dołączył atabeg Kwarkwaradze II $^{19}$. W obliczu otwartego konfliktu zbrojnego państwa europejskie jednak nie dotrzymały warunków umowy. Doprowadziło to do nieuniknionej porażki Ak Kojunlu z siłami tureckimi pod Otlukbeli

14 С.П. Карпов, Трапезундская империя и западноевропейские государства в XIII-XVвв., Moskwa 1981, s. 105; D. Rayfield, Edge of Empires, s. 158.

15 J.N. Kelly, Encyklopedia papieży, Warszawa 1997, s. 345-347.

16 F. Babinger, La date de la prise de Trébizonde par les Turcs (1461), Revue des études byzantines, t. 7 (1949), s. 205-207.

17 Państwo Białego Barana, konfederacja plemion turkmeńskich, rządząca wschodnią Anatolią i zachodnim Iranem do podboju wspomnianych terytoriów przez Safawidów. Zob. J.E. Woods, The Aqquyunlu: Clan, Confederation, Empire. A Study in 15th/9th Century Turko-Iranian Politics, Chicago 1976.

18 E. Mamistwaliszwili, Sakartwelo antiosmanur kaolicyaszy, Macne (1971), nr 3, s. 78; por. F. Babinger, La date de la prise, s. 306.

19 T. Lajoš, Put' Katarino Dzeno - posla Uzun-Gassana - Čerez Gruziju v Vengriju, Literaturnaja Gruzija, cz. 11 (1969), s. 129-135. 
11 VIII $1473 \mathrm{r}^{20}$ Rozgoryczony szach powetował sobie straty, najeżdżając... Gruzję. Chrześcijańska monarchia w opinii przemierzających Zakaukazie posłów weneckich, Giosafata Barbaro i Ambrogia Contariniego, mogła zaoferować już tylko „wino, owoce, chleb i baraninę"21. Zupełnie odmiennego zdania był niestrudzony Konstantyn II. Podjął on kolejną próbę nawiązania sojuszu z państwami europejskimi. Władca kartlijski marzył o usunięciu muzułmanów z regionu w wyniku dwutorowego ataku sił chrześcijańskich na Turków i Persów z Gruzji i... Maroka. Pomysł ten pojawił się po upadku w 1492 r. Grenady - ostatniego muzułmańskiego bastionu na Półwyspie Iberyjskim. Gruzini wysłali w 1495 r. delegację pod przewodnictwem dyplomatów Nilosa (Kornilos) ${ }^{22}$ i Zakarego ${ }^{23}$ do Hiszpanii i Papiestwa poprzez państwa Jagiellonów ${ }^{24}$. Poselstwo gruzińskie odwiedziło dwór księcia litewskiego, Aleksandra i króla węgiersko-czeskiego, Władysława II. Prawdopodobnie starania o zawiązanie sojuszu militarnego podjęto również na krakowskim dworze Jana I Olbrachta, gdzie trwały przygotowania do zbrojnej konfrontacji z Turcją o dominację w strefie czarnomorskiej. Źródła „milczą” o fakcie podjęcia bezpośrednich pertraktacji polsko-gruzińskich. W dbałości o bezpieczeństwo stanowisko Konstantyna II przedstawiono prawdopodobnie ustnie ${ }^{25}$. Finalnym etapem tworzenia koalicji było dostarczenie listów do Ferdynanda II Aragońskiego i Izabeli I Kastylijskiej oraz papieża Aleksandra VI, w których to Bagratyd słusznie uskarżał się na ucisk muzułmański, głównie „bezbożnych Persów”, tj. na obowiązki: „płacenia wielkich podatków,

\footnotetext{
20 F. Babinger, La date de la prise, s. 314-315; J. E. Woods, The Aqquyunlu, s. 131-137.

21 Cyt. za: D. Rayfield, Edge of Empires, s. 159-160.
}

22 Spis dokumentów sporządzony przez S. S. Kakabadze obejmuje list autorstwa Konstantyna II z dnia 10 III 1465 r. dla poselstwa Kornilosa vel Nilosa, kierującego się od państwa egipskiego sułtana Kairu wraz z posłami hiszpańskimi (napotkanymi przez dyplomatę w Jerozolimie) do królowej „Hiszpanii”, „Izabeli Aragońskiej” (Kastylijskiej). O ile droga poselstwa niesie ze sobą dozę prawdopodobieństwa, o tyle datacja dokumentu już nie i należy ją ze względu na okoliczności wystawienia listu, jego treść, a także pozycję korespondujących (w 1465 r. adresatka, przyszła władczyni zjednoczonego królestwa Hiszpanii, miała ok. 14 lat; nie posiadając ugruntowanej pozycji we własnym państwie, była pozbawiona perspektyw na tytuł kastylijski) przesunąć na lata tuż po upadku Grenady. Zob. С. С. Какабадзе, Грузинские документы Института Народов Азии АН CСCP, Moskwa 1967, s. 234.

23 M. Macharadze, Georgian-Ottoman relations in the 15th century, Tbilisi 2005, s. 98-100.

24 N. Jawachiszwili, Little-know pages of the history of Georgian-Baltic relations in the 10th-18th centuries, The Caucasus \& Globalization, t. 4 (2010), nr 3-4, s. 150.

25 Y. Tsintsadze, Materials to the History of Polish-Georgian relations (15th-17th centuries), Tbilisi 1965, s. 18-39. 
stałego udziału w szeregach wojskowych i przyjęcia mahometanizmu”26. Zachodnioeuropejscy przywódcy ograniczyli się jedynie do szczerych zapewnień o modlitwie i moralnym wsparciu dla Gruzinów ${ }^{27}$, zaś sam papież w charakterystyczny sposób dla kurii rzymskiej zaproponował królowi przystąpienie do ustaleń rady z FerraryFlorencji o prymacie Kościoła łacińskiego nad „Kościołem wschodnim” ${ }^{28}$. Na domiar złego „klęska mołdawska” wojsk polsko-litewskich jesienią 1497 r. zahamowała ekspansjonistyczne zapędy Jagiellonów w regionie czarnomorskim ${ }^{29}$. Prowadzona $\mathrm{z}$ rozmachem dyplomacja władców gruzińskich, wprzęgnięta w dyplomatyczne wysiłki chrześcijańskiej Europy, nie odniosła wymiernych sukcesów w drugiej połowie $\mathrm{XV}$ w. Zbyt wielkie były odległości między stolicami potencjalnych sojuszników, również nie mniejsze różnice interesów istniały między nimi.

Kolejne dziesięciolecia przyniosły istotne zmiany na arenie międzynarodowej. Odwracająca się gospodarczo ku nowym lądom Europa Zachodnia, jednocześnie pogrążająca się politycznie w chaosie wojen religijnych drżała na samą myśl o kolejnych podbojach potężnego Imperium Osmańskiego sułtana Sulejmana II Wspaniałego ${ }^{30}$, z którym to państwo polsko-litewskie, wyzbywając się zaborczej polityki zewnętrznej priorytetem uczyniło utrzymanie poprawnych stosunków. Ponadto ze wschodu Gruzinom zaczął zagrażać coraz wyraźniej perski ekspansjonizm Imperium Safawidów. Z każdym dziesięcioleciem sytuacja zakaukaskich chrześcijan stawała się coraz trudniejsza. W pierwszych dziesięcioleciach XVI w. tracące na znaczeniu papiestwo nie rezygnowało jednak z religijnej powinności odzyskania ziem świętych i dlatego też 16 III 1517 r., na zakończenie soboru laterańskiego V, papież Leon X zaapelował do władców chrześcijańskich o pokój w Europie oraz podjęcie wyprawy antytureckiej $^{31}$. Inicjatywę poparł cesarz Maksymilian I Habsburg, który na sejmie w Augsburgu w $1518 \mathrm{r}$. poprosił o angaż wasali cesarstwa, a następnie po rozmowach z posłem polskim Erazmem Ciołkiem wysłał poselstwo dla zjednania sobie Polski i Moskwy. Cesarską propozycję walki z Turkami wielkiemu księciu moskiewskiemu Wasylowi III przedstawił poseł Francisco de Colla. Gruzja w tych rozmowach (okre-

\footnotetext{
26 Cyt za: J. Kawtaradze, Gruzja w zarysie historycznym, Warszawa 1929, s. 65.

27 D. Rayfield, Edge of Empires, s. 163.

28 M. Papashvili, Georgian-Roman Relations, Tbilisi 1995, s. 110.

29 Zob. F. Papée, Jan Olbracht, Kraków 1936.

30 Określany w historiografii rodzimej również jako Prawodawca (tur.: Kanuni). Zob. Y. Öztuna, Kanuni Sultan Süleyman, Stambuł 2014.

31 M. Klein, Geschichtsdenken und Ständekritik in apokalyptischer Perspektive, Hamm 2004, s. 67.
} 
ślana jako „Иверия”), nie odgrywała jednak wówczas roli potencjalnego sojusznika, lecz stanowiła chrześcijańską część świata islamskiego ${ }^{32}$. Przy kolejnych próbach wiązania wrogich sił Osmanom, upadająca monarchia zupełnie była pomijana. Nie zmieniły tego również dostarczone przez wysłanników ormiańskich zapewnienia króla Kartlii Luarsaba I, o poddaniu się gruzińskich władców zwierzchnictwu stolicy apostolskiej ${ }^{33}$. Analogicznego rozgoryczenia politycznego zaznał jego następca - Simon I. Zwrócił się on 6 V 1596 r. do papieża Klemensa VIII, jako „duchowego Ojca”, o pomoc militarną i możliwość dołączenia do koalicji przeciwko panoszącym się Turkom w podległym mu królestwie ${ }^{34}$. Listy posłano również do króla hiszpańskiego Filipa II Habsburga i cesarza, Rudolfa II Habsburga ${ }^{35}$. Negocjacje nie przyniosły żadnych pozytywnych skutków, mimo iż trzy lata później do gry włączyła się dyplomacja Safawidów z planami rozmów antyosmańskich z ośmioma państwami europejskimi: papiestwem, cesarstwem, Hiszpanią, Francją, Anglią, Szkocją, Wenecją, a także Rzeczpospolitą. O ile państwa tworzące oś zwycięskiej Ligii Świętej spod Lepanto (papiestwo, Hiszpania) wraz z cesarstwem podjęły nieudolną i nic nieznaczącą dla poprawy losów Gruzji walkę z Wysoką Portą o władzę na Węgrzech w latach 1593-1606 (tzw. III wojna austriacko-turecka) ${ }^{36}$, o tyle państwo polsko-litewskie w wyniku awanturniczych „dymitriad” priorytetem polityki zagranicznej uczyniło obsadzenie moskiewskiego tronu.

Antagonizm polsko-rosyjski wypełniający pierwszą połowę XVII w. wykluczał podjęcie szeroko zakrojonej interwencji zbrojnej którejś ze wschodnioeuropejskich potęg w newralgicznym regionie, jednak więzi Gruzji ze światem chrześcijańskim nie zrywał. Bilateralne stosunki gruzińsko-polskie uległy de facto pogłębieniu i intensyfikacji na polu ekonomiki, zwiększając tym samym zainteresowanie Europy niewielką monarchią. W raporcie dla papieża Urbana VIII włoski podróżnik Pietro

32 Памятники дипломатических сношений с Империею Римскою. Том I. С 1488 по 1594, Sankt-Petersburg 1851, s. 356-371.

33 M. Tamaraszwili, Z. Aleksidze, J. Odisheli, Sakartvelos eklesiis istoria. Tsqaroebi, Tbilisi 1995, s. 519-521; M. Papashvili, Georgian-Roman Relations, s. 113.

34 M. Tamaraszwili, Z. Aleksidze, J. Odisheli, Sakartvelos eklesiis istoria, s. 523-524; M. Papashvili, Georgian-Roman Relations, s. 117, 121-122; I. Tabaghua, Sakartvelo evropis arkivebsa da tsignsatsavebshi (XIII-XV1 ss.), t. I, Tbilisi 1984, s. 156, 222, 227.

35 A.M. Ginio, Jews, Christians, and Muslims in the Mediterranean World After 1492, London 1992, s. 85.

36 K.M. Setton, Venice, Austria, and the Turks in the Seventeenth Century, Philadelphia 1991, s. 6-22. 
Della-Valle podkreślał w 1627 r., iż „król polski z (...) gruzińskimi książętami (Gurii z domu Gurieli i Megrelii ${ }^{37} \mathrm{z}$ domu Dadiani,) podtrzymuje przyjaźń i wymianę listów. Z jednego królestwa do drugiego często chodzą statki handlowe" ${ }^{38}$. Ożywienie czarnomorskiego handlu towarami luksusowymi: woskiem, futrami (lisy, tygrysy) i przyprawami korzennymi, a przede wszystkim najbardziej pożądanym jedwabiem było zasługą m.in. dalekowzrocznej polityki księcia Megrelii, Lewana II. Z pomocą i radą wybitnego dyplomaty Nikoloza Irubakidze-Czolokaszwiliego (znany na Zachodzie jako Nicefor Irbach) podjął on istotne kroki dla finalizacji kontraktów z odległą Francją, a zwłaszcza z bliższą jemu Rzeczpospolitą. Nie udało się podważyć ekonomicznej hegemonii Turcji w basenie Morza Czarnego, ale rozkwit wymiany towarowej między sojusznikami sprawil, że system monetarny zachodnich państewek gruzińskich w ciągu pierwszych dziesięcioleci XVII w. odżył w wyniku oparcia się na zdewaluowanej polskiej monecie ${ }^{39}$. Władca z rodu Dadiani próbował zadbać o niezależność swojego księstwa nie tylko na gruncie ekonomicznym, ale i politycznym. Ostatecznie Megrelia zacieśniła stosunki z polską Kozaczyzną zaporoską na tyle, że dyplomacja angielska, mająca placówkę w Konstantynopolu, określała je ze stanowczością jako „stałe” ${ }^{40}$. Wygnany zaś przez Persów z Kartlii i Kachetii Tejmuraz I również skierował swoje wysiłki dyplomatyczne ku Europie Zachodniej, korzystając z usług Nikoloza Irubakidze-Czolokaszwiliego (w 1625 r. $)^{41}$ i Pietra Avitabilego (w 1630 r. $)^{42}$, prosił (jak się okazało finalnie, nieskutecznie) o pomoc militarną zaangażowanych w wojnę trzydziestoletnią papieża Urbana VIII oraz króla Hiszpanii Filipa IV Habsburga ${ }^{43}$.

37 Księstwo Odiszi, określane od podboju carskiego w 1803 r. w języku rosyjskim jako Megrelia/Mingrelia, w języku gruzińskim nazywane Księstwem Samegrelo.

38 I. Cincadze, Meslebi polonetisa da sagartvelos urtiertobis istoriidan, Tibilisi 1996, s. 42; por. Iveria (1899), nr 3, s. 56-57.

39 N. Jawachiszwili, Little-know pages, s. 151-152; System monetarny wschodniej Gruzji pod rządami Rostoma całkowicie został podporządkowany perskiemu. Zob. D.W. Lang, The Last Years of the Georgian Manarchy, 1658-1832, Cambridge 1958, s. 29-30.

40 M. Swanidze, Gruzija, strany Priczernomoria $i$ Wostocznoj Jewropy w pierwojpotowinie XVII w. [w: ] Rossija, Polsza i Priczernomorie w XV-XVII ww., red. B.A. Rybakow, Moskwa 1979, s. 239-245.

41 J. Watejszwili, Грузия и европейские страны, т. I. Грузия и ЗапаАная Европа XIII-XVII вв., Moskwa 2003, s. 248-254.

42 M. Papashvili, Georgian-Roman Relations, s. 169-172.

43 Pozytywnym skutkiem dyplomacji było wydanie pierwszej drukowanej książki gruzińskiej pt. Dittionario giorgiano e Italiano w Rzymie w 1629 r., J. Watejszwili, Грузия и европейские страны, s. 378-440; M. Papashvili, Georgian-Roman Relations, s. 160-162. 
W drugiej połowie XVII w. kontakty władców gruzińskich oscylowały wokół utworzenia militarnego sojuszu antyosmańskiego, który to wówczas już nie tylko w dyplomacji, ale również na polu walki odnosił zwycięstwa. Król Imeretii Arczil II nawiązał stosunki z państwem polsko-litewskim, przyjmując w stołecznym Kutaisi posłów polskich: jezuitów o.o. Ignacego Zapolskiego i Jana Gostkowskiego w 1690 r. ${ }^{44}$ Podobną misję o 21 lat wcześniej, wiosną 1669 r., przeprowadził Gruzin Bohdan Gurdziecki, dyplomata w służbie Rzeczypospolitej, dostarczając poszczególnym Bagratydom listy również od cara Aleksego I Romanowa ${ }^{45}$. Rozmowy polsko-gruzińskie o udziale w tworzonej z inspiracji Polski, a z poparciem Rosji koalicji antytureckiej nie przyniosły działań rzeczywistych dla wyzwolenia Gruzji, były one zaledwie „łabędzim śpiewem” pogłębiającej się w kryzysie potęgi polskiej oraz dowodem na iluzoryczność „andruszowskiej” ${ }^{46}$ jedności obozu chrześcijańskiego. Pomimo podjęcia niepodległościowych dążeń gruzińskich państewek przez Rzeczpospolitą w sposób instrumentalny i bezskuteczny, monarchia ta stała się miejscem schronienia dla grup migrantów z Zakaukazia, głównie oferując przybyszom angaż $\mathrm{w}$ oddziałach wojskowych lub funkcje w dyplomacji ${ }^{47}$. Równie nieskuteczne były wówczas kontakty z papiestwem i prośby króla Kartlii, Jerzego XI z dniem 16 IV 1687 r., który to wysłał listy do papieża, Innocentego XI, zapewniając o swojej wierności Stolicy Apostolskiej i gotowości do walki z niewiernymi w ramach Ligii Świętej słowami, iż: „Wszystkie oddziały gruzińskie w naszym królestwie są gotowe i czekają na Twoje rozkazy, naszym marzeniem jest podążać za Twoimi rozkazami. Nie wątp w naszą lojalność. Pomimo, iż jesteśmy daleko, marzymy ujrzeć Ciebie”48. Papiestwo, otrzymujące podobne wyrazy lojalności (często potwierdzane przez samych wędrujących misjonarzy, na przykład duchownego Józefa [Jozefa] z końca

\footnotetext{
44 M. Tamaraszvili, Istoria katolikobisa kartwelta, Tbilisi 1902, s. 220; P. Avril, Podróż do różnych krajów Europy i Azji przez Misjonarzów S. J. w r. 1690 odprawiona końcem odkrycia nowej drogi do Chin, Warszawa 1791, s. 257.

45 G.E. Zedginidze, On the history of Polish-Russian diplomatic relations with Iran: The activities of Bogdan the Georgian, Tbilisi 1971.

46 Rozejm andruszowski z 1667 r., kończący konflikt polsko-rosyjski, potwierdzony pokojem Grzymułtowskiego w 1686 r. obligował Rzeczpospolitą i Rosję do wystąpienia przeciwko Imperium Osmańskiemu. L. Hubert, Pamiętniki historyczne, Warszawa 1861, t. 1, s. 116.

47 A. Woźniak, Z dziejów diaspory gruzińskiej w Polsce, Etnografia Polska, t. XXXVI (1992), z. 1, s. 83-84.

48 M. Papashvili, Georgian-Roman Relations, s. 221-224.
} 
XVII w. ${ }^{49}$ od wielu innych władców gruzińskich (m.in. od króla Kartlii-Kachetii Herakliusza (Irakliego) I oraz władców Kartlii: Kaihosro I i Wachtanga V) ${ }^{50}$, oferowało zniewolonemu Zakaukaziu jedynie wsparcie na podłożu kulturowo-naukowym (przyjmując studentów gruzińskich w progach rzymskiej uczelni) i religijnym, głównie w postaci organizacji oraz objęcia patronatem licznych misji katolickich, skierowanych zarówno do struktur podzielonego Kościoła gruzińskiego (z propozycjami zaakceptowania katolicyzmu na czele, czego przykładem są listy papieża Klemensa XI do katolikosa Domentiego z początków XVIII w. $)^{51}$, jak i samych wiernych, przez Turków i Persów nawracanych siłą na wiarę Mahometa.

Koniec XVII w. przyniósł osłabienie potęg muzułmańskich. Turcja po klęsce wiedeńskiej, popadając w głęboki marazm moralny, targana przez rewolty na szczytach władzy, nie zdołała podjąć skutecznej walki przeciwko Lidze Świętej - koalicji papiestwa, Wenecji, Austrii, Rzeczypospolitej i Rosji. Wynik tej konfrontacji został rozstrzygnięty bez udziału wojsk gruzińskich, a z dniem 26 I 1699 r., usankcjonowany ustaleniami karłowickimi, zamykał okres ekspansji osmańskiej na kontynencie europejskim, jednocześnie przy wewnętrznym osłabieniu drugiej z potęg muzułmańskich - Persji, predysponując w najbliższym okresie do roli głównego gracza w regionie kaukaskim zbliżającą się doń Rosję ${ }^{52}$. Mimo to, pragnący zrzucenia niewoli islamskiej król Kartlii Wachtang VI, początkowo zwrócił się o pomoc do przywódców państw Europy Zachodniej. Śmiertelnie przestraszony obowiązkiem złożenia hołdu i przyjęcia islamu przed obliczem szacha Husajna, wysłał on misję dyplomatyczną pod przewodnictwem swojego mentora, księdza Sulchana Saby Orbelianiego, na dwór króla Francji Ludwika XIV i papieża Klemensa XI ${ }^{53}$. Intensywność podjętego dialogu z władcami katolickimi w latach 1713/1714-1716 prawdopodobnie determinował ultrakatolicyzm autorytatywnego duchownego ${ }^{54}$ oraz przekonanie establishmentu tbiliskiego o nikłych szansach na interwencję rosyjską wobec zaangażowania militarnego cara Piotra I w trzeciej odsłonie rywalizacji o hegemonię nad Morzem Bałtyckim. Po powrocie w ojczyste strony Wachtang VI

49 D.M. Lang, The Last Years of, s. 83.

50 M. Tamaraszwili, Istoria katolikobisa kartwelta, s. 620-621.

51 Tamże, s. 306.

52 R.A. Abou-El-Haj, The Formal Closure of the Ottoman Frontier in Europe 1699-1703, Journal of the American Oriental Society, 89 (1969), nr 3, s. 467-475.

53 B. Al. Sulchan-Saba Orbeliani, Cchowreba da szemokmedeba, Tbilisi 1958, s. 8-14.

54 Г. Аеонилзе, Сулхан-Саба Орбелиани (1658-1725). Путешествие в Европу, Tbilisi 1969, s. 7-9. 
zmienił kierunek dyplomatycznych zabiegów, a konkretyzowały go kolejne przetasowania w układzie sił międzynarodowych.

Długotrwałą wojnę północną zakończył z dniem 30 VIII (10 IX) $1721 \mathrm{r}^{55}$ pokój z Nystad, umożliwiający zwycięskiej Rosji podjęcie przygotowań do podboju wybrzeży Morza Kaspijskiego. Pochód Piotra Wielkiego z lat 1722-1723 zakończył się jednak niepowodzeniem. Sojusznicze wojska rosyjskie wycofały się z regionu, a osamotniona Kartlia utraciła nadzieję na suwerenny byt ${ }^{56}$. Opuszczony Bagratyd już tylko listownie mógł się uskarżać na swój los zachodnioeuropejskim przywódcom: cesarzowi Karolowi VI Habsburgowi oraz papieżowi Innocentemu XIII, prosząc jednocześnie z dniem 29 XI 1722 r. o „interwencję któregoś z ich posłów u Porty, by odwrócić grożącą klęskę" ${ }^{7}$. Powtórnie codziennością stały się opresje muzułmańskich zaborców. Persja zemściła się na zdradliwym wasalu i usunęła Wachtanga VI z tronu. Już w czerwcu 1723 r. siły osmańskie zdobyły Gori i Tbilisi ${ }^{58}$. Zdewastowane najazdami perskimi, dagestańskimi i tureckimi Kartlia oraz sąsiednie ziemie gruzińskie stały się kartą przetargową w gorących pertraktacjach turecko-rosyjskich. Z dniem 12 (23) VI 1724 r. układem konstantynopolitańskim Rosja za cenę utrzymania zdobyczy na Persji w basenie Morza Kaspijskiego uznała hegemonię Turcji na Kaukazie z Azerbejdżanem, Armenią i całą Gruzją ${ }^{59}$. Początek osmanloby (tak Gruzini określali opresyjne rządy tureckie) zmusił zrozpaczonego Wachtanga VI do ewakuacji z licznym dworem (1286 osób). Za przyzwoleniem Piotra I (poselstwo Dawida Nazaraszwilego) odnalazł on schronienie w Rosji, ostatecznie w Astrachaniu, gdzie do końca swoich dni na pensji rządu rosyjskiego snuł plany odzyskania tronu $^{60}$. Rosja w okresie „popiotrowym” porzuciła, jednak zamiary uwolnienia Zakaukazia, a najdobitniejszym dowodem weryfikacji carskiej polityki zagranicznej było wycofanie się z basenu Morza Kaspijskiego po rzekę Sułak na rzecz paktów

\footnotetext{
55 А.А. Сазонов, Под стягом России: сборник архивных документов, 1993, s. 118-131.

56 Zob. В.П. Аысцов, ПерсиАский похоА Петра I 1722-1723, Moskwa 1951.

57 D.M. Lang, The Last Years of, s. 100-115; J. Kawtaradze, Gruzja w zarysie, s. 71-72.

58 Mühimme defterleri, 131, s. 190.

59 В.П. Аысцов, Персидский поход Петра, s. 237-238; por. P. Avery, G. Hambly, C. Melville, The Cambridge history of Iran. Volume 7: From Nadir Shah to the Islamic Republic, Cambridge 1991, s. 300.

60 Zob. С.М. Броневский, Исторические выписки о сношениях России с Персиею, Грузиею и вообще с горскими народами, в Кавказе обитающими со времен царя Ивана Васильевича Аоныне, Sankt-Petersburg 1996, s. 126.
} 
antytureckich zawartych z Persją w Raszcie (1732) i Gandży (1735) ${ }^{61}$. Za sprawą międzynarodowych ustaleń wschodnia część Gruzji popadła tym razem w dwunastoletnią kizilbaszobę (perską okupację) narzuconą przez wybitnego wodza Nadir Szacha ${ }^{62}$.

Pomimo tragicznych skutków „sojuszniczej” kampanii kaspijskiej z lat 1722-1723 kolejni władcy gruzińscy, nawet ci obdarzeni nietuzinkowym zmysłem dyplomatycznym, wierzyli w skuteczną opiekę pokrewnej religijnie i kulturowo Rosji. Zintensyfikowanie kontaktów na linii Tbilisi - Sankt Petersburg, przy jednoczesnym całkowitym wygaszeniu dyplomacji z pogrążającą się w marazmie ustrojowym i moralnym Warszawą, ograniczyło dialog ze stolicami zachodnioeuropejskimi. Tymczasem Turcja nadal stanowiła potęgę, która podczas jednej wyprawy wojennej mogła zmiażdżyć maleńkie państewka Bagratydów. W każdej chwili mogło również dojść do restauracji ekspansjonizmu Persji. Wiedział, o tym doskonale ambitny władca wschodniej Gruzji Herakliusz II, który energicznie zintensyfikował politykę, zacieśniając współpracę z Rosją (również na podłożu militarnym podczas konfliktu rosyjsko-tureckiego z lat $1768-1774^{63}$ ) oraz potwierdzając opisywaną przez rodzimą historiografię opinię polityka o szerokich horyzontach, skierował intensywnie zakrojoną, lecz ryzykowną akcję dyplomatyczną, ku głównym ośrodkom politycznym Zachodu.

W 1781 r. (misja ojca Dominika z Triestu) i 1782 r. (poselstwo ojca Mawrosa z Werony) Herakliusz II prosił cesarza Józefa II Habsburga o wsparcie polityczne, a przede wszystkim finansowe „na utrzymanie dwóch pułków” i szkolenie armii gruzińskiej według standardów europejskich, „tak aby (...) wrogowie nie ośmielili się podjęcia dalszych działań zbrojnych" ${ }^{64}$. Podobne wnioski wysłano do przywódców Francji, Prus, Neapolu, Sardynii, Republiki Weneckiej i papiestwa ${ }^{65}$. Misja dyplomatyczna do powyższych krajów zakończyła się jednak niepowodzeniem; jeden z wysłanników zmarł w Berdyczowie (Rzeczpospolita), drugi zaś w Stambule. Nie dość, że nie pozyskano żadnego sojusznika, to jeszcze o gruzińskich planach dowiedziały

\footnotetext{
61 D.M. Lang, The Last Years of, s. 117.

62 R. Suny, The Making of the Georgian Nation, Bloomington/Indianapolis 1994, s. 55.

63 А.И. Брегвадзе, Славнал страница истории. Аобровольное присоединение Грузии к России и его сочиально-економические последствия, Moskwa 1983, s. 45-59.

64 П.Г. Бутков, Материалы дяя новой истории Кавказа, с 1722 по 1803 гоА, Т. 3, SanktPetersburg 1869, s. 160, 164; D.M. Lang, The Last Years of, s. 181.

65 D. Rayfield, Edge of Empires, s. 247.
} 
się władze tureckie ${ }^{66}$. Aktywność dyplomatyczną Herakliusza II z niezadowoleniem przyjęły również władze rosyjskie. Wzmocnienie pozycji usamodzielniającego się królestwa Kartlii-Kachetii, łamiącego prawa lokalnych „azerbejdżańskich chanów”67, przy ewentualnym udziale Austrii lub Francji ograniczałoby w istotnym stopniu wpływy Rosji na Kaukazie. Katarzyna II postanowiła przejść do ofensywy, realizując plan rozbioru Turcji autorstwa swego faworyta Grigorija Aleksandrowicza Potiomkina. Po aneksji Krymu w dniu 8 (19) IV 1783 r. ${ }^{68}$ zgodziła się następnie na udzielenie protektoratu monarchii wschodniogruzińskiej. Doniosły akt „о признании царем Карталинским и Кахетинским Ираклием II покровительства и верховной власти России" zawarto 24 VII (4 VIII) 1783 r. w twierdzy Gieorgijewsk ${ }^{69}$. Za cenę militarnej ochrony przed islamskim jarzmem Herakliusz II zrezygnował de facto $\mathrm{z}$ atrybutów suwerenności podległego mu państwa, m.in. godząc się na likwidację autokefalii (do tej pory ciążącego ku Rzymie) rodzimego Kościoła (art. 8 - „Katolikos (...) otrzymał miejsce wśród rosyjskich arcybiskupów w ósmym stopniu, mianowicie po Tobolskim"), a co istotniejsze, zrzekając się prowadzenia niezawisłej polityki zagranicznej (art. 4 - „bez uprzedniej zgody od Głównego Urzędu Nadgranicznego i ministra Jej Wysokości przy nim akredytowanym, nie mieć stosunków z sąsiednimi władcami”).

Ustalenia gieorgijewskie uczyniły w kolejnych latach kontakty monarchii Bagratydów z Europą Zachodnią, zwłaszcza z papiestwem (roszczącym sobie prawa do zwierzchności nad miejscowym Kościołem), drugorzędnymi, tracącymi cechę bilateralnych i podmiotowych. Gruzja (Kartlia-Kachetia) ${ }^{70}$ stała się jedną z ofiar ekspansjonizmu Imperium Rosyjskiego. Na podstawie poczynań cara Aleksandra I, z literą aktów „Манифест к грузинскому народу” ${ }^{\prime 1}$ oraz „УчрежАение управления

\footnotetext{
66 B. Baranowski, K. Baranowski, Historia Gruzji, Wrocław 1987, s. 122.

67 О.П. Маркова, Россил. Закавказье и международные отномения в XVIII веке, 1966, s. 176.

68 M.S. Anderson, The Great Powers and the Russian Annexation of the Crimea, 1783-4, The Slavonic and East European Review, vol. 37 (1958), nr 88, s. 17-41.
}

69 А. Цагарели, Грамоты, Т. II, Sankt-Petersburg 1898, s. 99-110; Аоговор о признании иарем Карталинским и Кахетинским Ираклием II покровительства и верховной власти России (Георгиевский трактат), 24 июля 1783 г., [т:] Под стягом России: Сборник архивных документов, Moskwa 1992, s. 238-247.

70 Pod protektorat Rosji dostają się kolejno: księstwo Megrelii - 1801; królestwo Imeretii 1804 r., księstwo Gurii - 1811 r. (do tego czasu Guria była lennem Imeretii); księstwo Abchazji - 1809/1810; księstwo Swanetii - 1832 r. Zob. P. Prokopiuk, Walka Gruzji o niepodlegtość i integralność terytorialna w latach 1989-2008, Lublin 2010, s. 19, [Kaukaz.pl, dostęp 1.01.016]. 71 PSZRI I, t. 26 (1800-1801), № 20009; Высочайший манифест 12-го сентлбря 1801 года, 
Грузией”72 z 12 IX 1801 r., to już integralna pod względem administracyjnym i ustrojowym ${ }^{73}$ część Rosji. Z biegiem lat podlegała coraz bardziej na każdym innym polu państwowości rosyjskiej i w efekcie została wymazana na dziesięciolecia z map, a tym samym pozbawiona roli gracza oraz partnera w oficjalnej dyplomacji międzynarodowej, aż do decydujących rozstrzygnięć I wojny światowej ${ }^{74}$.

Nadesłany: 19 III 2017

Nadesłany po poprawkach recenzyjnych: 30 XI 2017

Zaakceptowany: 15 XII 2017

mgr Piotr Prokopiuk

Instytut Historii

Wydział Humanistyczny

Uniwersytet Marii Curie-Skłodowskiej w Lublinie

Plac Marii Skłodowskiej-Curie 4A

20-031 Lublin

bolshoiboozepiotr@onet.eu

\section{The relations between Georgia and Western Europe and the Polish- -Lithuanian Commonwealth in 1453-1783}

Following the fall of the Byzantine Empire (1453) and the Empire of the Trebizond (1461) the fragmented Georgia made a desperate attempt at participating in European countries' various efforts aimed at coalitions (political and military alike) against the Islamic Turkey posing a threat to the Christian world. In the $17^{\text {th }}$ century, the captive Bagrationi dynasty

[w:] Акты собранные Кавказской Археографической Коммиссиею, t. 1, Tyflis 1866, s. 432-433 .

72 PSZRI I, t. 26 (1800-1801), № 19770, 20007, 20009, Учреждение внутренняго правления в Грузии.

73 Zob. A. Górak, Ustrój administracji rosyjskiej na Kaukazie (1785-1844), [w: ] Kaukazw stosunkach międzynarodowych. Przeszłość, teraźniejszość, przyszłość, red. P. Olszewski, K. Borkowski, Piotrków Trybunalski 2008, s. 87-114.

74 Ostatnią „gruzińską” próbą nawiązania kontaktów z Europą Zachodnią, był list ostatniego króla Zachodniej Gruzji, Solomona II do cesarza Napoleona, kierującego wówczas inwazję na Rosję (1811-1812), z błaganiem: „racz uwolnić mnie razem z milionami chrześcijańskich dusz spod jarzma bezlitosnego Cesarza Moskwy”: cyt. za: J.P. de Tournefort, A Voyage into the Levant, Tbilisi 1988, s. 263-264. 
managed to build up lasting trade relations with the Polish-Lithuanian Commonwealth and intense cultural and religious contacts with the Papacy. The dynamically changing geopolitical system in the Caucasus region ultimately predestined the Russian Empire to become Georgia's natural ally in the subsequent century as no other country could offer tangible military assistance to Georgia.

Translated by: Ewa Dratwa 